\title{
Study on the Evaluation of the Construction Level of Provincial Ecological Civilization Based on Grey Relational Projection Method
}

\author{
Xia Feng ${ }^{1,2}$, Mu Zhang ${ }^{1}$ \\ Guizhou University of Finance and Economics 1. College of Big Data Application and Economics; 2. Guizhou Institute \\ of Innovation and Venture Capital \\ Guiyang,China \\ rim_007@163.com \\ 基于灰色关联投影法的省域生态文明建设水平评 \\ 价研究 \\ 冯霞 1,2 , 张目 ${ }^{1}$ \\ 贵州财经大学 1.大数据应用与经济学院;2.贵州科技创新创业投资研究院 \\ 贵阳 550025, 中国 \\ rim007@163.com
}

\begin{abstract}
Based on the "whole ecosystem" interpretation of the connotation of ecological civilization, this paper constructs an evaluation system of ecological civilization construction with 34 indexes including search engine data-Baidu index from four aspects: ecological environment, ecological economy, ecological livability and ecological culture. In order to better identify and guide the direction of ecological civilization construction, this paper introduces the grey relational projection method into the evaluation of the level of ecological civilization construction, establishes the evaluation model of ecological civilization based on the grey relational projection method, evaluates the state and construction process of ecological civilization in China's provinces from 2013 to 2017 by using the analytic hierarchy process, and compares the projection values of 30 provinces. The size of each province determines the level of ecological environment quality and the ranking of advantages and disadvantages, and carries out a comprehensive evaluation of the national level of ecological civilization construction, and puts forward specific strategic suggestions for the key direction of future ecological civilization construction in different regions.

Key words-ecological civilization construction evaluation system,search engine data,ecological civilization evaluation model, grey relational projection value.
\end{abstract}

摘要一基于对生态文明内涵的 “全生态” 解读, 从生态环 境、生态经济、生态宜居和生态文化 4 个方面出发, 构建了 包含搜索引擎数据-百度指数在内 34 项指标的生态文明建设 评价体系。为更好地识别与引导生态文明建设方向, 本文将 灰色关联投影法引入到生态文明建设水平评价当中, 建立了 基于灰色关联投影法的生态文明评价模型，运用摘权法对 2013-2017 年我国各省份生态文明的状态与建设过程两个方面 进行评价, 通过比较 30 个省份的投影值的大小, 确定各省份 所属的生态环境质量级别以及优劣排序, 并对全国生态文明 建设水平进行综合评价, 针对不同地区未来生态文明建设的 重点方向提出了具体的战略性建议。

\section{I. 引言}

为有序指导我国生态文明建设的具体实践工作，国 家环境保护部与发展改革委员会等相关部委及各省市出 台了一系列的生态文明建设评价体系，国务院先后印发 了《关于加快推进生态文明建设的意见》和《生态文明 体制改革总体方案》，关于生态文明建设的重大意义， 十八大报告指出：“建设生态文明，是关系人民福祉、 关乎民族未来的长远大计。”为深入贯彻党中央、国务 院关于加快推进生态文明建设的总体部署, 建立和完善 生态文明建设标准体系, 充分发挥标准化在生态文明建 设中的支撑和引领作用, 国家标准委组织编制了《生态 文明建设标准体系发展行动指南（2018-2020 年）》, 围绕坚决打好污染防治攻坚战, 建立健全生态文明建设 标准体系，加快制修订生态环境、空间布局、生态经济、 生态文化等生态文明建设急需的关键技术标准, 着力推 动生态文明建设标准应用实施, 推动建设人与自然和谐 共生的现代化，不断满足人民日益增长的优美生态环境 需要。足以可见构建生态文明建设评价指标体系对提升 生态文明建设的发展水平具有重要作用。

学者们从不同角度构建了一系列评价地区生态文明 建设的指标体系。虽然国外研究并没有直接反映生态文 明特征的指标体系, 但对环境保护、可持续发展等方面 的指标体系可为生态文明提供有益的借鉴参考 ${ }^{[1-2]}$ 。目前 国内学者构建的生态文明评价指标多通过指标法来选取, 从指标构成来看, 绝大多数文献都将环境类指标, 比如 森林覆盖率、环境空气质量优良率等纳入到生态文明指

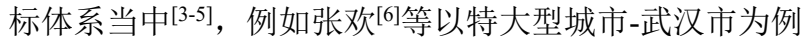
所构建的生态文明评价指标体系包含 4 个一级指标: 生 态环境的健康度、资源环境消耗强度、面源污染的治理 效率、居民生活宜居度, 20 个二级指标; 杜宇 ${ }^{[7]}$ 等从自 然、经济、社会、政治、文化 5 个角度设计出包含 34 个 
指标的生态文明建设评价指标框架,来衡量人与自然、 人与人、经济与社会之间的互动关系; 朱玉林[8]等以长 株潭城市群为例, 构建了一套较为完整的城市生态文明 评价指标体系。该指标体系主要包括生态经济、民生改 善、生态环境、生态治理和生态文化五个方面, 包含 28 个指标; 林震 ${ }^{90}$ 等对三个省会城市贵阳市、杭州市和南 京市的生态文明建设评价指标体系进行研究。本文在现 有研究的基础上, 创造性地将百度指数纳入到生态文明 建设指标体系当中，从而完善了生态文明建设评价体系， 目前, 百度指数已成功应用于股票价格预测、旅游、公 共文化服务体系、艾滋病疫情、农民工返乡关注度、房 地产价格等方面。陈洪 $[10]$ 结合百度指数提供的数据, 对 30 个省的艾滋病情况进行时空分析, 并给出及时监控措 施; 朱华戟 ${ }^{[11]}$ 以 2011-2014 百度指数为数据来源, 讨论 农民工返乡创业关注度的变化趋势; 姜文杰 ${ }^{[12]}$ 使用搜索 关键词的百度指数开展研究, 对上海市的新建住宅价格 指数进行了拟合和预测。百度指数是重要的互联网大数 据, 通过百度指数中关于生态文明关键词的搜索量体现 生态文化的普及度, 完善了生态文明建设评价指标体系, 鉴于此, 因此本文构建了包含百度指数在内的生态文明 建设评价指标体系, 运用熵权法确定各指标权重, 建立 基于灰色关联投影的生态文明评价模型, 比较灰色关联 投影值的大小，对全国生态文明建设水平进行优劣排序， 进而为全国生态文明水平的进一步发展提供新思路。

\section{II. 基于灰色关联投影的生态文明评价模型}

\section{建模步骤如下 ${ }^{[13-14]}$ :}

\section{步骤 1. 构建决策矩阵}

构造多指标决策域集合 $A$, 记 $A=\{$ 方案 1 , 方案 $2, \ldots$, 方案 $n\}=\left\{A_{1}, A_{2}, \ldots, A_{n}\right\}, A_{0}$ 是为最优方案; 构造因素指 标集合 $V$, 记 $\mathrm{V}=\{$ 指标 1 ,指标 $2, \ldots$,指标

$m\}=\left\{V_{1}, V_{2}, \ldots, V_{m}\right\}$, 则最优方案 $A_{0}$ 的属性值为 $Y_{0 j}$, 且 满足:

当因素指标 $V_{j}$ 属于效益型指标时, $Y_{0 j}=$

$\max \left(Y_{1 j}, Y_{2 j}, \ldots, Y_{n j}\right), j=1,2, \ldots, m$

当因素指标 $V_{j}$ 属于成本型指标时, $Y_{0 j}=$

$\min \left(Y_{1 j}, Y_{2 j}, \ldots, Y_{n j}\right), j=1,2, \ldots, m$

当因素指标 $V_{j}$ 属于固定型指标时, $Y_{0 j}$ 为该评估指标 的最佳稳定值, $j=1,2, \ldots, m$

决策方案 $A_{i j}$ 对指标 $V_{j}$ 的属性值为 $Y_{i j}$, 决策域集合 $A$ 对因素指标集 $V$ 的决策矩阵 $Y$ 如下: $\left(\begin{array}{ccc}Y_{01} & \cdots & Y_{0 m} \\ \vdots & \ddots & \vdots \\ Y_{n 1} & \cdots & Y_{n m}\end{array}\right)$ 即 $Y=\left(Y_{i j}\right)_{(n+1) \times m}, \quad i=0,1, \ldots, n, j=1,2, \ldots, m$

\section{步骤 2.初始化决策矩阵}

为消除量纲和量纲单位不同所带来的不可公度性, 应对因素指标进行极值化处理。

对于效益型指标, 令 $Y_{i j}{ }^{*}=Y_{i j} / \max Y_{i j}, i=$

$0,1, \ldots, n, j=1,2, \ldots, m(1)$

对于成本型指标, 令 $Y_{i j}{ }^{*}=\min Y_{i j} / Y_{i j}, i=$

$0,1, \ldots, n, j=1,2, \ldots, m(2)$

\section{步骤 3.构造灰色关联度决策矩阵}

以 $Y_{i j}{ }^{*}(i=1, \ldots, n, j=1,2, \ldots, m)$ 为子因素, $Y_{0 j}{ }^{*}$ $(j=1,2, \ldots, m)$ 为母因素, 则母因素与子因素之间的 关联度用 $r_{i j}$ 表示, 即最优方案与其他决策方案之间的关 联度, $r_{i j}$ 的计算如下:

$$
r_{i j}=\frac{\min \min \left|Y_{0 j}{ }^{*}-Y_{i j}{ }^{*}\right|+\lambda \max \max \left|Y_{0 j}{ }^{*}-Y_{i j}{ }^{*}\right|}{\left|Y_{0 j}{ }^{*}-Y_{i j}{ }^{*}\right|+\lambda \max \max \left|Y_{0 j}{ }^{*}-Y_{i j}{ }^{*}\right|}
$$

式中: $\lambda$ 是分辨系数, $0<\lambda<1$, 通常取 $\lambda=0.5$,

由 $r_{i j}(i=0,1,2, \ldots, n ; j=1,2, \ldots, m)$ 组成的灰色关联度决 策矩阵为: $R=\left(r_{i j}\right)_{(n+1) \times m}$, 显然, $R_{01}=R_{02}=\cdots=$ $R_{0 n}=1$

\section{步骤 4.运用摘值赋权法确定因素指标的权重系数 \\ 步骤 5. 确定加权灰色关联决策矩阵}

记指标权重向量为 $W_{k}=\left(w_{1}, w_{2}, \ldots, w_{m}\right)^{T}$, 则对灰 色关联度决策矩阵 $R$ 加权后得到加权灰色关联决策矩阵 $R^{\prime}$,且满足:

$$
\begin{gathered}
R^{\prime}=R \cdot W=\left(R_{1}{ }^{\prime}, R_{2}{ }^{\prime}, \ldots, R_{m}{ }^{\prime}\right) \\
R^{\prime}=\left[\begin{array}{cccc}
w_{1} & w_{2} & \cdots & w_{m} \\
w_{1} r_{11} & w_{2} r_{12} & \cdots & w_{m} r_{1 n} \\
& \vdots & \ddots & \vdots \\
w_{1} r_{m 1} & w_{2} r_{m 2} & \cdots & w_{m} r_{m n}
\end{array}\right]
\end{gathered}
$$

\section{步骤 6. 计算灰色关联投影值}

记决策方案与最优方案之间的灰色关联投影夹角为 $\theta_{i}$, 则:

$$
\begin{aligned}
\cos \theta_{i} & =\sum_{j=1}^{m} r_{i j} w_{j}{ }^{2} / \sqrt{\sum_{j=1}^{m} w_{j}{ }^{2}} \sqrt{\sum_{j=1}^{m}\left(r_{i j} w_{j}^{2}\right)^{2}}, i \\
& =1,2, . . n
\end{aligned}
$$

决策方案 $A_{i}$ 在最优方案上的投影值为灰色关联投影 值 $D_{i}$ : 


$$
\begin{gathered}
D_{i}=\left\|A_{i}\right\| \cdot \cos \theta_{i}=\sum_{j=1}^{m} r_{i j} w_{j}{ }^{2} / \sqrt{\sum_{j=1}^{m} w_{j}^{2}}, i \\
=1,2, \ldots n \\
R^{\prime}=\left[\begin{array}{cccc}
w_{1} & w_{2} & & w_{n} \\
w_{1} r_{11} & w_{2} r_{12} & \cdots & w_{m} r_{1 n} \\
& \vdots & \ddots & \vdots \\
w_{1} r_{m 1} & w_{2} r_{m 2} & \cdots & w_{m} r_{m n}
\end{array}\right]
\end{gathered}
$$

步骤 6.计算灰色关联投影值 $\theta_{i}$, 则:

记决策方案与最优方案之间的灰色关联投影夹角为

$$
\begin{gathered}
\cos \theta_{i}=\sum_{j=1}^{m} r_{i j} w_{j}^{2} / \sqrt{\sum_{j=1}^{m} w_{j}{ }^{2}} \sqrt{\sum_{j=1}^{m}\left(r_{i j} w_{j}{ }^{2}\right)^{2}} \\
=1,2, \ldots n
\end{gathered}
$$$$
, i
$$
值 $D_{i}$ :

决策方案 $A_{i}$ 在最优方案上的投影值为灰色关联投影

$$
\begin{aligned}
& D_{i}=\left\|A_{i}\right\| \cdot \cos \theta_{i}=\sum_{j=1}^{m} r_{i j} w_{j}{ }^{2} / \sqrt{\sum_{j=1}^{m} w_{j}{ }^{2}}, i \\
& =1,2, . . n
\end{aligned}
$$

III. 省域生态文明建设水平实证分析

生态文明指标的选择对于准确评估生态文明建设水 平具有重要作用, 本文在构建指标体系时遵循综合性与 代表性、针对性与可比性、导向性与前瞻性的原则, 同 时考虑到数据的可获得性、科学性以及可操作性, 本文 以 30 个省份为研究对象, 评价其 2013 年至 2017 年这五 年内的生态文明建设的发展水平, 从生态经济、生态环 境、生态宜居以及生态文化四个方面出发, 构建了包含 34 个二级指标的生态文明建设指标体系，见表 1 。

表 1 .省域生态文明建设水平评价体系

目标层

一级指标

生态经济

生态文明建设水平

生态环境

生态宜居

生态文化

二级指标

服务业增加值占 GDP 的比重（\%）；R \& D 经费支出占 GDP 的比重（\%）；人均生产 总值（元）; 单位 GDP 能耗（吨煤/万元）; 单位 GDP 煤炭消耗（吨碳/万元）; 单位 GDP 石油消耗（吨石油/万元）；单位 GDP 建设用地（公顷/亿元）; 单位 GDP 废水排 放量（吨/万元）；高新技术产业产值占规模以上工业产值的比重（\%); 主要饮用水源水质达标率 (\%); 工业用水重复利用率 $(\%)$ ；空气质量优良天数 （天）；区域环境噪声平均等效声级（分贝）；二氧化硫排放量（万吨）；化学需氧量 排放量（万吨）；氨氮排放量（万吨）；氮氧化物排放量（万吨）；空气质量达到二级 标准的天数比例 $(\%)$ ；地表水好于III类水质的比例（\%）; 工业固体废弃物综合利用 率 (\%); 城市生活污水集中处理率（\%)；城市生活垃圾无害化处理率（\%) 建成区绿化覆盖率 (\%) ; 人均公园绿地面积 (平方米) ; 万人拥有公交车辆（辆/万 人)；森林覆盖率（\%)；城区绿化覆盖率（\%)；城区人口密度（人/平方千米）；城 区人均道路面积 (平方米) ; 城区人均住房面积 (平方米)

文化产业增加值占 GDP 比重（\%）；居民文化娱乐消费支出占消费总支出比重（\%）; 百度指数 $\mathrm{pc}$ 端搜索量（次）; 百度指数移动端搜索量（次）

数据来源：本文样本期间选定为 2013 年至 2017 年，以 30 个省份（西藏地区数据暂无）为研究对象，各项生态 文明指标的原始数据主要来源于各省份统计局发布的 2014-2018 统计年鉴、各省份环境保护局发布的环境公告和水资 源公报，篇幅有限，原始数据略。

步骤 1.针对 30 个省份，构造多指标决策域集合 $A$, 以及包含 34 个指标的指标集 $V, 34$ 个指标中有 11 个指 标属于成本型指标, 23 个指标属于效益型指标。即可得 到最优方案
$A_{0}=80.6,6.08,128927,0.2672,0.0310,0.0471,0.0209,0$. $1196,55.6,100,96.55,363,47.2,1.43,5.75,0.56,6.1,99.5,98.2,9$ $8.99,97.71,100,48.4,19.77,26.55,66,48.42,1059,25.82,54.13$

\begin{tabular}{|c|c|c|c|c|c|c|c|c|c|c|c|c|c|c|c|c|}
\hline 81 & 6.1 & 128927 & 0.3 & 0.0310 & 0.0411 & 0.0209 & 0.1 & 56 & 100 & 97 & 363 & 47.2 & 1 & 5.8 & 1 & 6 \\
\hline 78 & 6.1 & 94648 & 0.3 & 0.10 & 0.07 & 0.08 & 0.5 & 22 & 100 & 42 & 176 & 53.9 & 9 & 17.9 & 2 & 17 \\
\hline 48 & 3.0 & 100105 & 0.5 & 0.37 & 0.11 & 0.05 & 1.3 & 31 & 100 & 94 & 175 & 53.9 & 22 & 22.2 & 2 & 31 \\
\hline 36 & 1.0 & 38909 & 1.0 & 1.11 & 0.05 & 0.04 & 3.9 & 24 & 100 & 94 & 129 & 53.1 & 128 & 131.0 & 11 & 165 \\
\hline 42 & 1.2 & 34984 & 1.6 & 2.89 & 0.06 & 0.06 & 3.6 & 13 & 98 & 92 & 183 & 52.9 & 126 & 46.1 & 6 & 116 \\
\hline
\end{tabular}
21.6,16.16,94,81

根据已知的最优方案和指标集，列出决策域集合 $A$ 对指标集 $V$ 的属性矩阵 $Y$ ，属性矩阵 $Y$ 的第一行是最优方案。 (以 2013 年的数据为例)

表 2. 决策域集合 $A$ 对指标集 $V$ 的属性矩阵 $Y$ 


\begin{tabular}{|c|c|c|c|c|c|c|c|c|c|c|c|c|c|c|c|c|}
\hline 37 & 0.7 & 67836 & 1.0 & 2.06 & 0.06 & 0.06 & 1.6 & 14 & 96 & 88 & 205 & 52.8 & 136 & 86.3 & 5 & 138 \\
\hline 41 & 1.7 & 1996 & .8 & 0.67 & 0.15 & 0.07 & .1 & 26 & 99 & 90 & 182 & 57.9 & 103 & 125.3 & 10 & 96 \\
\hline 36 & .9 & 4428 & 0.7 & 80 & 08 & .07 & 2.9 & 24 & 94 & 77 & 335 & 4.2 & 38 & 76.1 & 5 & 56 \\
\hline 42 & 1.2 & 7697 & 0.8 & .92 & 13 & .10 & 2.9 & 22 & 95 & 58 & 339 & 54.3 & 49 & 144.7 & 9 & 75 \\
\hline 63 & 3.6 & 90993 & 0.5 & 0.26 & 0.16 & 0.09 & 2.1 & 23 & 100 & 67 & 241 & 55.5 & 22 & 23.6 & 5 & 38 \\
\hline 46 & 2.5 & 75354 & 0.5 & 0.47 & 0.05 & 0.05 & 3.7 & 22 & 100 & 86 & 220 & 54.5 & 94 & 114.9 & 15 & 134 \\
\hline 48 & 2.2 & 68805 & 0.5 & 0.38 & 0.07 & 0.05 & 5.0 & 24 & 100 & 78 & 250 & 55.7 & 59 & 75.5 & 11 & 75 \\
\hline 34 & 1.9 & 2001 & 0.6 & 0.81 & 0.06 & 0.08 & 3.9 & 30 & 98 & 96 & 316 & 53.9 & 50 & 90.3 & 10 & 86 \\
\hline 40 & 1.4 & 58145 & 0.5 & 0.37 & 0.08 & 0.04 & 4.8 & 20 & 99 & 87 & 362 & 55.4 & 36 & 63.9 & 9 & 44 \\
\hline 35 & 0.9 & 30 & 0.5 & 0.50 & 0 & 0.06 & 4. & 20 & 98 & 50 & 316 & 54 & 56 & 73.5 & 9 & 57 \\
\hline 42 & 2.2 & 56885 & 0.6 & 68 & 0.07 & $0 .($ & 3. & 25 & 100 & 91 & 200 & 47.2 & 165 & 184.6 & 16 & 165 \\
\hline 36 & 1.1 & 34211 & 0.7 & 0.78 & 0.06 & 0.05 & 3.9 & 23 & 92 & 93 & 324 & 50.9 & 125 & 135.4 & 14 & 157 \\
\hline 40 & 1.8 & 42826 & 0.6 & 0.49 & 0.09 & 0.06 & 3.1 & 22 & 98 & 87 & 315 & 53.9 & 60 & 105.8 & 12 & 61 \\
\hline 41 & 1.3 & 36943 & 0.6 & 0.46 & 0.06 & 0.06 & 3.6 & 16 & 97 & 42 & 324 & 54.6 & 64 & 124.9 & 16 & 59 \\
\hline 49 & 2.3 & 58833 & 0.4 & 0.27 & 0.08 & 0.05 & 2. & 18 & 97 & 90 & 319 & 55.1 & 76 & 173.4 & 22 & 120 \\
\hline 38 & 0.8 & 30741 & 0.6 & 0.51 & 0.07 & 0.07 & 6.2 & 17 & 96 & 93 & 349 & 54.3 & 47 & 75.9 & 8 & 50 \\
\hline 52 & 0.5 & 35663 & 0.5 & 0.32 & 0 & 0.06 & 0. & 20 & 98 & 60 & 362 & 58 & 32 & 19.4 & 2 & 10 \\
\hline 47 & 1.4 & 43223 & 0.6 & 0.45 & 0 & 0.0 & 2. & 21 & 96 & 31 & 206 & 53.5 & 55 & 39.2 & 5 & 36 \\
\hline 36 & 1.5 & 32617 & 0.7 & 0.44 & 0 & 0.0 & 2. & 23 & 92 & 82 & 325 & 53.7 & 82 & 123.2 & 14 & 62 \\
\hline 47 & 0.6 & 23151 & 1.1 & 1.69 & 0.08 & 0.03 & 2.2 & 10 & 93 & 81 & 278 & 55.6 & 99 & 32.8 & 4 & 56 \\
\hline 43 & 0.7 & 25322 & 0.9 & 0.83 & 0.08 & 0.05 & 2.6 & 21 & 98 & 38 & 333 & 55 & 66 & 54.7 & 5 & 52 \\
\hline 36 & 2.1 & 43117 & 0.7 & 1.06 & 0.07 & 0.06 & 2.2 & 21 & 97 & 89 & 329 & 53.5 & 81 & 51.9 & 6 & 76 \\
\hline 43 & 1.1 & 24539 & 1.1 & 1.03 & 0.14 & 0.10 & 3.8 & 12 & 94 & 95 & 261 & 50.1 & 56 & 37.9 & 4 & 44 \\
\hline 36 & 0.7 & 36875 & 1.8 & 0.98 & 0.1 & 0.06 & 2. & 19 & 99 & 48 & 266 & 52.5 & 16 & 10.3 & 1 & 13 \\
\hline 43 & 0. & & 1.9 & J. & U & 0. & J. & 1 & 97 & 92 & 251 & 53 & 39 & 22.2 & 2 & 44 \\
\hline 41 & 0.5 & 37553 & 1.6 & 1.68 & 0.15 & 0.05 & 1.1 & 24 & 98 & 10 & 280 & 56.7 & 83 & 67.2 & 5 & 89 \\
\hline
\end{tabular}

续表:

\begin{tabular}{|c|c|c|c|c|c|c|c|c|c|c|c|c|c|c|c|c|}
\hline 99.5 & 98.2 & 99 & 98 & 100 & 48 & 19.8 & 26.6 & 66 & 48 & 1059 & 26 & 54.1 & 21.6 & 16 & 94 & 81 \\
\hline 48.2 & 49.8 & 84 & 85 & 99 & 47 & 12.7 & 24.4 & 36 & 46 & 1289 & 8 & 31.3 & 13.0 & 15 & 94 & 36 \\
\hline 48.0 & 13.6 & 99 & 90 & 97 & 35 & 11.0 & 19.0 & 10 & 31 & 2843 & 19 & 35.8 & 21.3 & 8 & 59 & 21 \\
\hline 35.3 & 48.57 & 42 & 95 & 83 & 41 & 14.1 & 12.6 & 23 & 37 & 2483 & 18 & 33.7 & 5.8 & 10 & 62 & 32 \\
\hline 50.3 & 46 & 65 & 88 & 88 & 40 & 11.2 & 9.9 & 18 & 34 & 3526 & 13 & 31.1 & 8.0 & 14 & 53 & 31 \\
\hline 56.2 & 59.7 & 49 & 88 & 94 & 36 & 16.9 & 8.6 & 21 & 33 & 1059 & 20 & 29.6 & 8.1 & 11 & 44 & 24 \\
\hline 50.0 & 14.8 & 44 & 90 & 88 & 40 & 11.1 & 11.2 & 38 & 37 & 1663 & 12 & 30.8 & 3.4 & 8 & 58 & 31 \\
\hline 91.9 & 70.6 & 81 & 84 & 61 & 31 & 11.8 & 10.2 & 40 & 28 & 3135 & 14 & 28.3 & 3.1 & 12 & 49 & 26 \\
\hline 92.9 & 53.3 & 68 & 76 & 54 & 36 & 12.1 & 12.6 & 43 & 33 & 4922 & 13 & 27.2 & 3.0 & 9 & 58 & 29 \\
\hline 66.0 & 48.9 & 67 & 87 & 91 & 38 & 7.1 & 12.1 & 11 & 34 & 3809 & 4 & 31.5 & 4.6 & 15 & 67 & 30 \\
\hline 60.3 & 45.8 & 93 & 92 & 97 & 42 & 14.0 & 14.2 & 16 & 39 & 2016 & 23 & 44.2 & 5.0 & 12 & 74 & 38 \\
\hline 68.4 & 63.8 & 93 & 89 & 99 & 40 & 12.4 & 14.6 & 59 & 36 & 1818 & 18 & 48.2 & 3.3 & 10 & 79 & 36 \\
\hline 86.6 & 67.6 & 79 & 96 & 99 & 40 & 12.5 & 11.0 & 28 & 35 & 2359 & 20 & 33.8 & 2.9 & 10 & 61 & 30 \\
\hline 99.4 & 95.2 & 80 & 87 & 98 & 43 & 12.6 & 12.7 & 66 & 39 & 2570 & 13 & 38.7 & 2.7 & 10 & 67 & 49 \\
\hline 86.7 & 80.8 & 54 & 83 & 93 & 45 & 14.1 & 9.2 & 60 & 42 & 4542 & 15 & 40.9 & 2.7 & 12 & 49 & 28 \\
\hline 55.0 & 50.7 & 52 & 95 & 100 & 43 & 16.8 & 13.5 & 17 & 38 & 1361 & 25 & 36.4 & 3.0 & 10 & 72 & 35 \\
\hline 89.3 & 45.8 & 75 & 91 & 90 & 38 & 9.6 & 9.1 & 22 & 33 & 4982 & 12 & 39.6 & 2.3 & 12 & 66 & 38 \\
\hline 86.2 & 87 & 67 & 92 & 85 & 38 & 10.8 & 11.6 & 38 & 33 & 2505 & 16 & 41.7 & 3.0 & 10 & 63 & 33 \\
\hline 89.0 & 89.9 & 64 & 88 & 96 & 38 & 9.0 & 10.8 & 48 & 34 & 3317 & 14 & 40.2 & 5.4 & 11 & 60 & 33 \\
\hline 87.5 & 78.2 & 91 & 92 & 85 & 42 & 15.9 & 13.1 & 51 & 37 & 3066 & 13 & 31.8 & 4.2 & 9 & 88 & 45 \\
\hline 95.8 & 81.8 & 73 & 86 & 96 & 38 & 11.5 & 9.4 & 57 & 33 & 1543 & 16 & 36.1 & 2.8 & 12 & 49 & 27 \\
\hline 99.1 & 90.8 & 53 & 75 & 100 & 42 & 12.5 & 11.5 & 55 & 37 & 1946 & 19 & 30.3 & 2.3 & 12 & 26 & 12 \\
\hline 56.4 & 73.4 & 85 & 94 & 99 & 42 & 18.0 & 11.6 & 38 & 38 & 1847 & 11 & 33.6 & 3.5 & 10 & 51 & 28 \\
\hline 89.2 & 70.5 & 52 & 83 & 95 & 38 & 11.2 & 14.6 & 35 & 34 & 2900 & 13 & 36.6 & 3.4 & 9 & 62 & 33 \\
\hline 76.2 & 83.6 & 57 & 94 & 92 & 34 & 11.4 & 9.6 & 37 & 31 & 3406 & 10 & 34.8 & 2.0 & 14 & 63 & 32 \\
\hline
\end{tabular}




\begin{tabular}{|r|r|r|r|r|r|r|r|r|r|r|r|r|r|r|r|r|}
\hline 91.2 & 70.4 & 52 & 92 & 88 & 38 & 10.6 & 11.6 & 50 & 34 & 2415 & 12 & 43.5 & 2.1 & 5 & 50 & 27 \\
\hline 90.1 & 54.2 & 77 & 89 & 96 & 40 & 11.8 & 16.3 & 41 & 34 & 5541 & 15 & 35.0 & 2.7 & 13 & 60 & 33 \\
\hline 71.4 & 80 & 56 & 81 & 42 & 32 & 11.8 & 10.4 & 11 & 28 & 3916 & 14 & 30.9 & 2.6 & 10 & 42 & 22 \\
\hline 73.1 & 85.7 & 56 & 62 & 78 & 31 & 9.7 & 14.5 & 6 & 29 & 2924 & 11 & 32.8 & 1.7 & 11 & 10 & 5 \\
\hline 68.8 & 60.6 & 73 & 94 & 93 & 38 & 17.5 & 13.2 & 12 & 37 & 1253 & 19 & 32.2 & 2.2 & 12 & 20 & 6 \\
\hline 76.7 & 94.76 & 63 & 88 & 78 & 36 & 10.1 & 14.4 & 4 & 33 & 4361 & 16 & 25.0 & 2.7 & 11 & 33 & 17 \\
\hline
\end{tabular}

步骤 2. 通过对决策矩阵 $Y$ 进行初值化处理, 得到初始 化决策矩阵 $Y^{*}$

步骤 3. 根据计算所得的最优方案与其他决策方案之 间的关联度, 构建灰色关联判断矩阵 $R$, 这里取分辨系 数的取值为 0.5

步骤 4. 采用熵权法对各项指标赋权, 由于本文所采 用的指标中, 效益型指标是大者为优, 成本型指标是小 者为优, 将原始数据进行无量纲化, 然后计算出各项指 标的熵值, 进而得到一组加权系数

$W=0.051,0.055,0.045,0.046,0.051,0.057,0.026,0.023,0$ $.015,0.017,0.013,0.022,0.046,0.031,0.039,0.04,0.034,0.022$, $0.015,0.024,0.009,0.009,0.016,0.017,0.035,0.03,0.022,0.03$ $4,0.013,0.015,0.078,0.018,0.017,0.016$.

步骤 5. 根据步骤 4 得到的加权系数, 即可确定加权 灰色关联决策矩阵 $R^{\prime}$

步骤 6. 以 2013 年北京市为例, 计算灰色关联投影值 $D_{1}=\left\|A_{1}\right\| \cdot \cos \theta_{1}=\frac{0.038}{0.196}=0.193$, 则 2013 年 30 个省份的投 影值为:

$D_{2013}=(0.193,0.189,0.177,0.176,0.177,0.179,0.183,0.17$ $9,0.187,0.180,0.183,0.181,0.184,0.183,0.177,0.177,0.182,0$. $181,0.180,0.183,0.189,0.185,0.181,0.180,0.182,0.181,0.181$, $0.185,0.179,0.178)$
同理，对于 2014、2015、2016、2017 年的决策方案 在理想方案上投影值为:

$D_{2014}=(0.193,0.190,0.179,0.177,0.179,0.181,0.184,0.18$ $0,0.189,0.182,0.185,0.182,0.185,0.184,0.179,0.179,0.183,0$. $183,0.182,0.184,0.191,0.186,0.182,0.177,0.184,0.182,0.183$, $0.187,0.180,0.179)$

$D_{2015}=(0.194,0.190,0.180,0.178,0.179,0.181,0.185,0.18$ $1,0.190,0.183,0.185,0.183,0.186,0.184,0.179,0.180,0.184,0$. $183,0.183,0.186,0.191,0.187,0.183,0.183,0.185,0.183,0.183$, $0.188,0.181,0.18)$

$D_{2016}=(0.193,0.190,0.179,0.178,0.179,0.181,0.184,0.18$ $1,0.189,0.182,0.185,0.183,0.186,0.184,0.179,0.179,0.183,0$. $183,0.182,0.185,0.190,0.187,0.183,0.182,0.184,0.183,0.183$, $0.187,0.180,0.180)$

$D_{2017}=(0.195,0.191,0.181,0.179,0.182,0.183,0.187,0.18$ $3,0.190,0.184,0.187,0.182,0.188,0.185,0.182,0.184,0.186,0$. $186,0.184,0.186,0.191,0.188,0.181,0.183,0.185,0.185,0.185$, $0.187,0.182,0.181)$

为了更客观的评价各省份的生态文明建设发展水平, 对同一地区不同年份的投影值取平均值，见表 2 。

$\bar{D}=(0.1935,0.1899,0.1791,0.1778,0.1792,0.1809,0.1845$, $0.1810,0.1889,0.1823,0.1850,0.1821,0.1861,0.1841,0.1792$, $0.1800,0.1835,0.1832,0.1822,0.1848,0.1904,0.1867,0.1821$, $0.1809,0.1841,0.1827,0.1830,0.1867,0.1803,0.1797$ )

表 3. 全国生态文明建设的灰色关联平均投影值及排名

\begin{tabular}{|c|c|c|c|c|c|c|c|c|}
\hline 省份 & 平均投影值 & 排名 & 省份 & 平均投影值 & 排名 & 省份 & 平均投影值 & 排名 \\
\hline 北京 & 0.1935 & 1 & 浙江 & 0.1850 & 8 & 海南 & 0.1904 & 2 \\
\hline 天津 & 0.1899 & 3 & 安徽 & 0.1821 & 20 & 重庆 & 0.1867 & 6 \\
\hline 河北 & 0.1791 & 29 & 福建 & 0.1861 & 7 & 四川 & 0.1821 & 19 \\
\hline 山西 & 0.1778 & 30 & 江西 & 0.1841 & 11 & 贵州 & 0.1809 & 23 \\
\hline 内蒙古 & 0.1792 & 27 & 山东 & 0.1792 & 28 & 云南 & 0.1841 & 12 \\
\hline 辽宁 & 0.1809 & 22 & 河南 & 0.1800 & 25 & 陕西 & 0.1827 & 16 \\
\hline 吉林 & 0.1845 & 10 & 湖北 & 0.1835 & 13 & 甘肃 & 0.1830 & 15 \\
\hline 黑龙江 & 0.1810 & 21 & 湖南 & 0.1832 & 14 & 青海 & 0.1867 & 5 \\
\hline 上海 & 0.1889 & 4 & 广东 & 0.1822 & 18 & 宁夏 & 0.1803 & 24 \\
\hline 江苏 & 0.1823 & 17 & 广西 & 0.1848 & 9 & 新疆 & 0.1797 & 26 \\
\hline
\end{tabular}


通过比较表 3 中平均投影值的大小, 可以看出, 2013-2017 年期间, 北京市生态文明建设水平最高, 其 平均投影值为 0.1935 ; 山西省生态文明建设处于倒数第 一位, 其平均投影值是 0.1778 , 与北京市的平均投影值 相差 0.0157 。总体来看, 五年内我国 30 个省份的生态 文明建设状况各有差异。在生态环境建设方面, 广西、 青海、云南、四川等西部省份排名靠前, 陕西、吉林、 辽宁、海南和黑龙江等省份则排名靠后; 在生态经济发 展方面, 北京、天津、江苏、上海、浙江等经济发达地 区表现较好, 河北、广西、海南、青海和新疆等经济相 对落后地区表现欠佳; 在生态文化宣传方面, 北京、上 海、浙江、江苏等经济发达地区排名领先, 辽宁、陕西、 河南、湖南、河北等省份则排名靠后。

主动建设行为相对积极, 主要集中在东部沿海地区, 包括江苏、浙江、上海、广东、陕西、湖南、重庆、安 徽 8 个省份, 这些省份的生态文明建设成效在全国处于 领先地位。以下省份生态环境现状欠佳, 但主动建设行 为相对积极, 包括北京、天津、宁夏、湖北、山东、河 南、青海 7 个省份。这些省份虽然生态环境基础较为薄 弱, 但在生态文明建设过程中付出了比其他省份更大的 努力。以下省份生态环境现状相对较差, 主动建设行为 也相对落后, 主要集中在东北地区和西部地区, 包括河 北、山西、辽宁、黑龙江、四川、新疆、甘肃、吉林 8 个省份。这些省份的生态环境状况与生态文明建设力度 在全国处于全面落后状态, 应将其列为重点关注对象, 这类省份应加大对生态环境保护与建设的投入, 采取更 强的力度加快推进经济、政治、文化与社会的生态化进 程, 逐步从根本上改善地区的生态环境状况。以下省份 生态环境现状优良, 但主动建设行为相对落后, 主要集 中在西南内陆地区和南部沿海地区, 包括内蒙古、山东、 江西、广西、贵州、云南 6 个省份。这些省份的生态环 境状况虽然在全国相对领先, 但其在生态文明建设过程 中的投入还相对不足。

\section{IV. 结论}

生态文明建设评价指标体系的构建不仅可以用来评 价地区生态文明建设状况, 还可以科学引导不同地区未 来生态文明建设的重点方向。根据灰色关联投影值得到 的排名并不是构建生态文明建设评价指标体系的最终目 的, 找出各省份在建设过程中存在的问题更加重要。

从整体上来看, 我国东部省份的生态文明建设的平 均水平高于中部地区, 中部地区又高于西部地区。排名 最后的山西省, 应加强对生态环境的保护而不是一味地 发展经济而破坏环境; 排名倒数第四的新疆, 其重点短
板在于物质文明生态化方面, 如新疆的资源与能源使用 效率低下, 土地的集约化程度仅为上海的十分之一, 能 源利用效率仅为北京的五分之一, 提高资源与能源的经 济产出效率成为新疆生态文明建设下一步的重点方向。 这类省份应加大对生态环境保护与建设的投入, 采取更 强的力度加快推进经济、政治、文化与社会的生态化进 程, 逐步从根本上改善地区的生态环境状况。

\section{致谢}

本文获得国家自然科学基金地区项目（71861003） 和 2017 年度第二批贵州省基础研究计划 (软科学类别) 项目 “贵州大数据产业集聚效应及金融支持体系研究”

（黔科合基础（2017）1516-1）资助。

$$
\text { 参考文献 }
$$

[1] Magdoff F.Ecological civilization [J].Monthly Review-an independent Socialist Magazine,2011,62(8):1-25.

[2] United Nations Department of Economic and Social Affairs. Indicators of sustainable development: Guidelines and methodologies $[\mathrm{M}]$. Third Edition. New York: United Nations, 2007: 39-85..

[3] 杜宇,刘俊昌.生态文明建设评价指标体系研究 [J].科学管理研 究,2009(3):60-63.

[4] 林震, 双志敏.省会城市生态文明建设评价指标体系比较研究一以贵阳市、杭州市和南京市为例[J].北京航空航天大学学报(社会 科学版),2014,27(05):22-28.

[5] 王然.中国省域生态文明评价指标体系构建与实证研究[D].中国地 质大学, 2016 .

[6] 张欢,成金华,冯银,陈丹,倪琳,孙涵.特大型城市生态文明建设评价 指标体系及应用一一以武汉市为例[J].生态学报, 2015,35(02):547556.

[7] 杜宇,刘俊昌.生态文明建设评价指标体系研究[J].科学管理研 究,2009(3):60-63.

[8] 朱玉林,李明杰,刘旖.基于灰色关联度的城市生态文明程度综合评 价——以长株潭城市群为例[J].中南林业科技大学学报(社会科学 版),2010,4(05):77-80..

[9] 林震, 双志敏. 省会城市生态文明建设评价指标体系比较研究一以贵阳市、杭州市和南京市为例 [J]. 北京航空航天大学学报(社会 科学版),2014,27(05):22-28.

[10] 陈洪, 肖蓬,陈鹏. 基于百度指数的艾滋病疫情时空分析 [J].福建师 范大学学报(自然科学版),2016,32(03):14-18.

[11] 朱华晟,丁玥,方明.我国农民工返乡创业关注度的空间格局一一基 于 2011-2014 年百度指数的分析[J].改革与战略,2016,32(04):8792.

[12] 姜文杰, 赖一飞,王恺. 基于百度指数的房地产价格相关性研究 $[\mathrm{J}]$. 统计与决策,2016(02):90-93.

[13] 张目,周宗放.基于灰关联投影寻踪的企业信用评估模型[J].统计与 决策,2009(21):35-37.

[14] 张目,周宗放.基于多目标规划和支持向量机的企业信用评估模型 [J].中国软科学,2009(04):185-190. 